\title{
Exhibition projects as a technology of educational activity of higher school
}

\author{
Z. Yu. Zhelnina ${ }^{1 *}$, and E. Yu. Tereshchenko ${ }^{2}$ \\ ${ }^{1}$ Department of Services and Tourism, Murmansk Arctic State University, Russia \\ ${ }^{2}$ Department of Arts and Design, Murmansk Arctic State University, Russia
}

\begin{abstract}
The educational technologies of higher education are changing in the context of the growing influence of creative industries, the priority of the values of over-professional competencies and the expansion of the range of tasks associated with the development of cultural processes in the territories. The article discusses ways of modifying exhibition activities, where proprietary technologies are rapidly developing, trends in digitalization and event practices are strong, including performances, happening, master classes. Universities are involved in creative practices, but such work requires pedagogical logic, a methodology for involving young people in this area. The purpose of the study was to search for reliable methods and resources necessary for a successful strategy for the development of the art space of the university. Analysis of training courses related to exhibition work, an overview of the sites available for the presentation of youth projects, student surveys on motivation in the field of creative initiatives have become methods of obtaining the initial research data. As a result, it is concluded that it is necessary to develop the art space of the university as an independent educational practice, including for the development of open massive online courses and the formation of art collections in the multimedia format.
\end{abstract}

\section{Introduction}

Modern universities pay great attention to project technologies in the implementation of the tasks of professional training and the development of students' creative initiative. As you know, the product is very important in the project, it can be tangible or intangible, but its assessment can be obtained if the product is involved in the activity or presented in any exhibition space. At the same time, the technologies of exhibition activities are rapidly developing, and by now we can say that exhibitions occupy their own professional niche with differentiated competencies of specialists in museum expositions, urban art spaces, craft workshops, art galleries, trade and industrial exhibitions, and the MICE-industry etc. This situation is not accidental; it manifests itself in line with the trends of new urbanism, aestheticization of the environment, the convergence of creativity and everyday life, the multiplication of forms of business cooperation, and the growth of value turnover in the economy of impressions.

* Corresponding author: zzhelnina@yandex.ru 
The experience economy creates a new map of value added and technologies for ensuring the quality of life [1]. This trend is included in the mainstream of concepts of new urbanism [2]; [3], but at the same time forms a new polarization of the urban community [4]. Nevertheless, a significant number of studies argue that it is education that ensures the stability of the development of society, including conditions for innovation and creative entrepreneurship [5].

In line with the development of creative industries, exhibition projects simultaneously show their versatility in educational activities. Many areas of professional training now cannot do without the presentation of learning outcomes in the exhibition space. In addition, if earlier these were applied projects in art, design or engineering education, now tourism, service, media journalism, librarianship and many other areas have become specialties related to exhibition work. Many educational programs began to focus on the formation of emotional experience and then emotional intelligence; the volume of research in this segment has reached a fundamentally new level [6].

A review of research on educational technologies makes it possible to apply various methods of identifying trends and subject areas for the development of the practice of higher education [7]. At the same time, such studies reflect the nonlinear problems of the development of higher education [8] and make it possible to assess the role of art and the humanities in technological and economic innovations in the development of industries and territories [9]. Creative industries are taking more and more place directly in the educational technologies of universities [10]. This situation significantly changes the project-oriented teaching at the university [11].

Despite the growth in the turnover of information and applied solutions in the field of exhibition projects, several problems should be highlighted that manifest themselves in the field of educational practices. One of the important problems is the lack of exhibition spaces that can be freely used for educational activities, since museums, galleries, exhibition halls are focused on their own work plans, are bound by business obligations, economic tasks, therefore educational exhibition projects appear here only occasionally. Other problems continue the first one, since the lack of spaces and exhibition events minimize the personal experience of students, reduce the possibility of achieving special competencies already at the stage of university studies. Therefore, it is very important for the university to form its own practice of exhibition work, to create an existing art space and its development program.

It should be emphasized that the exhibition space of the university should be technologically progressive, events should be held here that will allow the university to compete in the segment of exhibition activities. This raises the problem of developing and implementing a long-term strategy for the exhibition space of the university with the involvement of the most advanced experience of galleries, exhibitions and related practices. In the system for assessing the success of such a strategy, it is logical to include both educational objectives, for example, student involvement and the number of exhibition projects, and indicators of the importance of the exhibition space for the city and the region.

Murmansk Arctic State University (MASU) is the main university in the region. Its work is largely related to the tasks of increasing the attractiveness of life in the Murmansk region, which represents the western sector of the Russian Arctic. In line with research into the specifics of the development of the Arctic regions, more and more attention is paid to humanitarian technologies and resources of creative industries, which significantly change the appearance of industrial cities in the Arctic [12]. Cultural events and creative clusters constitute a new force, which is taken into account, among other things, in economic investment projects, since these creative industries have a great influence on the social capital of the territory [13]. 
The relevance of the study, the purpose of which is to search for reliable methods and resources necessary for a successful strategy for the development of the art space of the university, is determined by the growth of technological solutions for exhibition work, as well as by the complex of educational tasks that the university must implement in the mainstream of the professional training of students.

\section{Materials and methods}

The development of a strategy for the development of the university's art space is included in the segment of its design and creative activities, is included in the general Development Strategy of MASU, this was preceded by work on holding events and implementing grants related to creative student projects focused on the creation of art objects and social spaces to improve quality urban environment. Student projects entered into collaboration with scientific research in the framework of the project "Creative City - Territory of Development" [14].

The experience of the implementation of this university project was presented at several international conferences and to date, several educational courses have been formed on its basis for such areas of training bachelors as "Design", "Tourism", "Service", as well as the master's program "Art Education and Media Design" ... These training courses reveal the specifics of the functioning of creative industries and end with projects, which certainly actualizes the task of systematizing the collective portfolio and increasing the productivity of the art space itself, where exhibition activities will be combined with master classes and professional discussions. Such an art space at MASU is the gallery "Otpechatok" $\dagger$, where exhibitions of works by students, artists and designers, who are guests and partners of the university, are continuously held. The gallery's work is well-known and diverse, but at the same time there is a need to achieve a new level of the gallery's activity [14].

It should be emphasized that the search for a solution lies in the field of educational technologies; here the intentions and initiative of the students themselves are important, interesting results are obtained from a survey of students, which allows establishing the potential of their activity in art spaces and mastering the competencies of exhibition activities [15].

To form an ambitious but realistic strategy for the development of the gallery's activities, it is necessary to analyze the active creative platforms of the city of Murmansk and the Murmansk region. In addition, to determine the expectations of the professional and local community, which become customers and consumers of the activities of the art space of the university [16]. The results of such a study in comparison with the potential of educational programs make it possible to form the concept of the art space of the university, to identify the points of growth of students' project competencies.

It should be emphasized that the search for a solution lies in the field of educational technologies, here the intentions and initiative of the students themselves are important, therefore, interesting results are obtained from a survey of students, which allows us to establish the potential of their activity in art spaces and mastering the competencies of exhibition activities.

Thus, a review of the activities of active exhibition spaces in the region, a comparative analysis of their productivity, taking into account the existing trends in the life of creative clusters, media platforms will allow to establish significant benchmarks not only for the development of exhibition projects of the university, but also for improving educational courses and technologies for practical training of students, shaping their experience in the creative industries segment.

† The name "Otpechatok" is translated as "imprint". 


\section{Results}

An assessment of the development of exhibition activities in the Murmansk region should begin with an overview of cultural institutions on the territory of which it is possible to hold public art exhibitions.

The exhibition hall of the city of Murmansk (v-zal.murm.muzkult.ru) is an institution whose main task is to promote the work of professional and amateur artists, as well as masters of decorative arts; satisfaction of the aesthetic needs of the population of the city and region. Exhibition activities are diverse: personal exhibitions, photo exhibitions, exhibitions of arts and crafts, exhibitions of children and youth creativity, exhibitions from private collections.

Murmansk Regional Art Museum (artmmuseum.ru). The main objective of the museum is the promotion of contemporary art, including the art of Murmansk artists, traditions of Russian art crafts. A large number of personal exhibitions are organized annually in the museum. For example, the annual exhibition "Arctic", which exhibited the work of artists from different cities of the Murmansk region. Each year, the art museum hosts young fashion designers and designers of the of the fashion festival.

Murmansk Regional Museum of Local Lore (mokm51.ru). In addition to permanent exhibitions, the museum annually holds over 100 exhibitions. A distinctive feature is that the museum provides services for organizing traveling exhibitions. The museum of local lore provides exhibition space for exhibitions of state and public organizations and institutions, collections of individuals, young artists of the Murmansk region, students.

The Murmansk Regional Universal Scientific Library (http://www.mgounb.ru) represents the information and cultural center of the region, where exhibitions of local artists and photographers are also held. In the history of the library, exhibitions related to important city competitions were held, for example, in 2011, sketches of the monument "Waiting" (an artistic image of a woman waiting for sailors and fishermen from the watch) were presented here, this monument has become one of the symbols of Murmansk, for whom the port became the basis of his life. [17]

Apatity City Palace of Culture named after V.K. Egorov (www.muagdk.ru) is the main cultural center for the development and support of the creative potential of the population of Apatity (it's a regional city of the Murmansk region). The Palace of Culture has thirty creative groups, amateur associations and circles. The administration actively supports initiatives in creating various creative groups, organizing exhibitions of both local artists and international projects.

Museum and Exhibition Center AO «Apatit» (www.mvc-apatit.ru) corporate Museum of Group of Companies «PhosAgro». It is one of the most striking and most visited tourism sites in the city of Kirovsk, the Murmansk region. The museum and exhibition center includes 8 halls of the main exposition of the corporate mining and geological museum, the exhibition center, the exposition "Life and customs of the Russian Empire", as well as a multimedia exhibition on the 7 floors of the clock tower "Journey from the bowels of the Earth into the atmosphere". In addition to excursions, the Museum and Exhibition Center hosts interactive events for all age groups - from preschool children to students and adults. The center provides an exhibition hall and a gallery for personal exhibitions, and actively supports local artists.

The Palace of Culture "Metallurg", the city of Kandalaksha (www.dkkandalaksha.ru), on a fee basis, provides its services in providing a foyer for exhibitions of paintings, photographs, products of craftsmen, enterprises, organizations and institutions.

The Center for Culture and Leisure "Polar Star", the city of Olenegorsk (https://polyarstar.ru) organizes exhibition activities, but in most cases, preference is given to large exhibitions and fairs. 
It should be noted that there are no private commercial organizations on the territory of the Murmansk region that provide their services for holding any kind of exhibitions, and existing official institutions work with ready-made art collections. Therefore, it can be determined that the region is experiencing a shortage of art infrastructure, where creative activities, experimental and educational exhibitions can be deployed.

Another problem can be considered the low level of representation of materials related to artistic creation and creative events in the media space of the region. The most complete is the news feed with brief notes and remarks about art events on the official websites of museums and cultural institutions. Now almost all municipal institutions in the field of culture have personal sites that provide information about the types of activities, a poster, a photo gallery and archive, a list of paid services.

At the same time, work on the development of such areas as multimedia museums, galleries and thematic guides-navigators for travelers are at a starting level, which is largely due to the gaps in the professional training of current specialists in the art sphere. These gaps appeared in connection with the increasing role of digital technologies, for which it is necessary to change the content, structure and form of presentation of materials, monitor the speed of updates, and also the task arose to combine subject exhibitions with their virtual counterpart. In fact, now we need teams with a new vision of art sites and new approaches to managing their activities.

A review of successful experience and scientific publications, revealing the subject field in the discussion of art venues and exhibition spaces as the infrastructure of the creative industry, shows that there are several active areas here. Here are the most discussed topics:

- the role of the exhibition space for the presentation of artistic creation, including the support of artists, photographers, craft-masters representing local communities;

- transformation of the exhibition area into art spaces, where performance and happening become their integral part;

- updating cultural programs and educational courses in the format of "lifelong education", when the exhibitions is formed as a result of an educational projects with components of creativity and self-expression of students;

- Installation of exhibition spaces into the "smart city" model, when human knowledge and creativity are revealed through digital technologies, and Internet of things and postinformation aesthetics come to museums and art clusters [18].

The review of publications devoted to trends and challenges in higher education technologies allows us to agree that the priority of the technology of "flipped learning", support of personal creativity, student involvement in interdisciplinary projects, variability of curricula based on a large number of miner courses that provide precise vocational guidance [19]. A significant trend is shown by the number of publications on the topic of gamification in higher education technologies [20]. These factors make up the ecosystem (external environment) of the life of the exhibition projects involved in educational practices. Objective data show that there is an unmet need for the development of creative clusters and qualified specialists who are ready to deal with this area in the region on a professional basis.

Art gallery "Otpechatok" is an exhibition space organized on the territory of the Murmansk Arctic State University. Numerous exhibitions of students' and teachers' works are held annually. The gallery organizes and conducts projects in the field of creative industries, supports the initiative in the development of the creative potential of young artists and hospitably welcomes honored artists. The gallery is actively involved in exhibiting the results of creative projects within the framework of the strategic project "Creative City - Territory of Development". In the system of tasks of modernizing her work, the most important and difficult are the creation of her virtual analogue and an increase in the number of participants in an educational course that presents exhibition 
work not only as an artistic and aesthetic activity, but also as a product of the experience economy.

\section{Discussion}

Educational technologies associated with the functioning of exhibition spaces, as well as those that create competencies for organizing exhibitions, are, in fact, accelerators for the development of the Murmansk as a region's creative capital. In this regard, it is necessary to discuss ways of transforming ordinary exhibition spaces into creative clusters, that is, places where creative initiatives, resources and those who are consumers and co-producers of creative products and art events meet. This is becoming a key topic of discussion in technologies for the formation of special and over-professional competencies.

One can hear the objection that the art space of the university will always remain an educational platform, and minor topics and mistakes of student exhibition projects will not allow it to become a driver of the region's creative life. Another objection is based on the opinion that the participation of famous artists and masters turns the art space into an orthodox gallery, a celebrity museum. Both objections reveal the question of the university's advantages as an organizer of art space.

These objections can be closed if a large number of events of various types are held in the art space of the university, and master classes are organized for educational projects to improve the level of their concepts and products. In addition, provided that the multimedia platform of the art space is activated, all projects (with the permission of the authors) will not only constitute a virtual collection, but will also be useful cases for educational practice.

The strategy for the development of the university's art space can get several points of growth. They can be listed:

- coordination of plans for events of art space and creative workshops to create projects"umbrellas", which allows you to mix and combine resources;

- creation of a sustainable long-term schedule of "free exhibitions" (non-format, open access) to attract creative forces;

- transformation of the training course on exhibition activities into the format of a massive open online course, which will increase the number of interested and competent participants in the art space;

- creation of a wide range of multimedia art collections for educational and free creative activities.

- formation of educational games for mastering art content and increasing motivation for creativity.

Such solutions reflect the principles of life-long education, increase the role of the university in intensifying the creative practices of the region, and parallel work in digital mode will change the speed of information circulation and expand the number of participants. Of course, it is worth discussing the criteria for the success of an art gallery as an educational project. Since it can be offered as an additional (miner) training course, the dynamics of the number of course participants, as well as the variety of thematic projects involved in the work of the art gallery should be assessed. The development process of the art gallery of the university should be built in a dialogue with participants in educational courses of various profiles, this will increase the number of work scenarios, which will give an impetus to the search for new forms of education. 


\section{Conclusion}

Teaching technologies of higher education are always focused on the initiative and responsibility of students in mastering knowledge, project and creative cases are important for upgrading their competencies. The infrastructure of the educational process of the $21 \mathrm{st}$ century is diverse and flexible, universities are actively using the potential of creative clusters and small art spaces to form specialized and supra-professional competencies for students of various training profiles. In this case, the educational process becomes part of the cultural life of the city and region.

Exhibition projects, presenting the achievements of students, require presentation in society and discussion by experts, but the main thing is to involve them in the further circulation of creative activity. At the same time, the university, using active forms of exhibition work: master classes, performances, happening, forms a new experience that is valuable for the creative life of the city and the region. The industrial history of the Murmansk region is a factor of special sensitivity to the quality of the cultural side of life, the potential of its creative capital.

Art gallery "Otpechatok" is actively working as an exhibition space, but the task of the Murmansk Arctic State University is to strengthen its potential as an accelerator for training specialists in creative industries, a testing ground for the introduction of digital technologies for creative tasks and educational activities. This approach will increase not only the authority of the university, but will also contribute to the attractiveness of the region as a unique Arctic territory, where various art events take place and creative capital is formed.

The article was written within the framework of the strategic project of the Murmansk Arctic State University "Creative City - Territory of Development", where exhibition projects are an integral part of orders for the development of the urban environment, projects in the future become materials of educational courses for students of various areas of training (http://www.masu.edu.ru/flagship/projects/gorod/).

\section{References}

1. T. Adashova, N. Rogoten The transformation of urban space as a factor in the development of the experience economy in Sovremennye problemy servisa i turizma. Tom 13. No 2. S. 34-41. DOI: 10.24411/1995-0411-2019-10203 (2019)

2. N. Ivankina, M. Perkova The concept of new urbanism: development prerequisites and basic provisions in Vestnik BGTU im. V.G. SHuhova. No 8. S. 75-84. DOI: 10.12737/article_5b6d585f08a625.50385604 (2018)

3. A. Ponomareva, T. Ignatova Development of a matrix of innovative and creative city development based on the index method in Journal Of Economic Regulation. Tom 9. No 3 S. 37-47 DOI: 10.17835/2078-5429.2018.9.3.037-047. (2018)

4. SH. Zukin The Cultures of Cities. - M., 424 s. (2015)

5. G. Grosseck, L. Tîru, R. Bran Education for sustainable development: Evolution and perspectives: A bibliometric review of research, 1992-2018 in Sustainability 2019; 11(21):6136. DOI: 10.3390/su11216136 (2019)

6. R. Smith, W. Killgore, R. Lane. The structure of emotional experience and its relation to trait emotional awareness: a theoretical review in Emotion. 18(5): 670-692. DOI: 10.1037/emo0000376. (2018)

7. L. Raickaya Review of surveys as a tool for identifying trends in the studied area of knowledge in Vysshee obrazovanie v Rossii. T. 29. No 3. S. 37-57.

DOI: 10.31992/0869-3617-2020-29-3-37-57. (2018) 
8. M. Pevnaya, E. SHuklina Institutional traps of nonlinear development of higher education in Russia in Integraciya obrazovaniya. T. 22, No 1. S. 77-90. DOI: 10.15507/1991-9468.090.022.201801.077-090. (2018)

9. J. Linton Implicit Actors: The Contribution of the Arts, Humanities and Social Sciences to Innovation in Forsajt. Tom. 12. No 3. S. 6-12. DOI: 10.17323/25002597.2018.3.6.12 (2018).

10. A. Trubeckaya Creative Industries: Experience in Applying a Practice-Oriented Approach in Russian Modern Education in Observatoriya kul'tury. Tom 16. No 3. S. 240-250. DOI: 10.25281/2072-3156-2019-16-3-240-250 (2019)

11. V. KHamidulin Modernization of the project-oriented learning model in the university in Vysshee obrazovanie v Rossii. 2020. Tom 29. No 1. S. 135-149.

DOI: 10.31992/0869-3617-2020-29-1-135-149 (2020)

12. A. Gushchina, M. Ivanova, D. Kondratovich, O. Polozhenceva Northern Dimension: perceptions of the population of the Murmansk region about the prospects for the development of the Russian Arctic, the effectiveness of social management, material well-being in Sever i rynok: formirovanie ekonomicheskogo poryadka. 2017. No 5. S. 13-24. DOI: 10.25702/KSC.2220-802X-5-2017-56-13-24 (2017)

13. The Strategy of socio-economic development of the Murmansk region until 2020 and for the period until 2025: approved by the Government of the Murmansk region dated December 25, 2013 No. 768-PP / 20 (as amended on July 10, 2017 No. 351-PP). URL: [https://minec.gov-murman.ru/activities/strat_plan/sub02/].

14. T. Ashutova, Z. ZHelnina Strategic project «creative city - territory of development» as a model of interaction between flagship university and region in Vysshee obrazovanie v Rossii. No 3 S. 116-126. DOI: 10.31992/0869-3617-2019-28-3-116-126 (2019)

15. Z. Zhelnina, E. Tereshchenko The influence of the cultural industry market on the quality of life of the population of the arctic regions in International Scientific-Practical Conference on Business Cooperation (ISPCBS, May 2019) Pp. 183-186. DOI 10.2991/ispcbc-19.2019.46 (2019)

16. V. Belova, O. Kolesova, I. Pomorina, R. Oplakanskaya «Town and gown»: university in the urban socio-economic and cultural-historical space of Europe (on the example of Great Britain, Germany, France and Poland) in Vestnik Tomskogo gosudarstvennogo universiteta. Istoriya. No 6(44). S. 87-97. DOI: 10.17223/19988613/44/12 (2016)

17. A. Samsyka Monument to the Waiting Woman in Murmansk: the role of the public in the monumental and sculptural decoration of Murmansk on the example of the monument "Waiting": a historical and art study. Murmansk. - URL: [http://kolanord.ru/html_public/col_avtory/SamsykaAA/SamsykaAA_PamyatnikZhduschej_2018/4/index.html] (2018)

18. E. Samojlova, Y. SHaev Art space of the Smart city: development prospects in Istoricheskie, filosofskie, politicheskie i yuridicheskie nauki, kul'turologiya i iskusstvovedenie. Voprosy teorii i praktiki. - Tambov: Gramota. No 12(86): v 5-ti ch. CH. 4. Pp. 150-153. (2017)

19. D. Van Alten, C. Phielix, J. Janssen, L. Kester Effects of flipping the classroom on learning outcomes and satisfaction: A meta-analysis in Educational Research Review. 2019;28:100281. DOI: 10.1016/j.edurev.2019.05.003. (2019)

20. G. Signori, J. De Guimarães, E. Severo, C. Rotta Gamification as an innovative method in the processes of learning in higher education institutions in International Journal of Innovation and Learning, 24(2), 115-137. DOI: 10.1504/IJIL.2018.094066 (2018). 